\title{
ECCENTRICALLY-INDUCED FATIGUE IN VOLUNTARY MUSCLE PERFORMANCE: THE EFFECT OF MUSCLE LENGTH AND CONTRACTION TYPE
}

\author{
Albertas Skurvydas, Marius Brazaitis, Sigitas Kamandulis, Dalia Mickevičienė, \\ Diana Karanauskienè \\ Lithuanian Academy of Physical Education, Kaunas, Lithuania
}

\begin{abstract}
Research background and hypothesis. We hypothesized that eccentric exercise (EE) would induce muscle fatigue and damage, which are dependent not only on muscle length tested but and on contraction type (eccentric vs. concentric vs. isometric) as well.

Research aim was to test the hypothesis.

Research methods. Healthy untrained men (mean \pm SD: age $=24.8 \pm 3.7$ years, $n=10$ ) performed 10 series of 12 repetitions of eccentric knee contractions at $160 \mathrm{deg} / \mathrm{s}$. The maximal voluntary isometric contraction force (MVC) of the quadriceps muscle, the maximal rate of torque development (RTD) and isokinetic torque at $30 \mathrm{deg} / \mathrm{s}$ were established before and after EE. All measures were performed at different knee angles. Besides, the EMG of the quadriceps muscle was measured.

Research results showed a significant change in absolute values of RTD after EE (before EE: $3695 \pm 803 \mathrm{~N} \cdot \mathrm{m} / \mathrm{s}$ and $2360 \pm 695 \mathrm{~N} \cdot \mathrm{m} / \mathrm{s}$ at SL and LL respectively; after EE: $2574 \pm 843 \mathrm{~N} \cdot \mathrm{m} / \mathrm{s}$ and $1517 \pm 476 \mathrm{~N} \cdot \mathrm{m} / \mathrm{s}$ at SL and LL respectively). A significant difference between EMG (rms) in MVC was found after EE at LL and SL, i. e. in v.lateralis $0.32 \pm 0.12 \mathrm{mV}$ and $0.24 \pm 0.1 \mathrm{mV}$ and in r.femoris $0.25 \pm 0.11 \mathrm{mV}$ and $0.17 \pm 0.07 \mathrm{mV}$ respectively. All criteria of voluntary performance changed significantly after EE except for RTD, i.e. it increased after EE.

Discussion and conclusions. We observed more changes in isokinetic torque at shorter muscle length after eccentric exercise-induced muscle fatigue and damage. The changes in MVC and RTD after eccentric exercise did not depend on the length of the muscle tested. Besides, relative RTD did not change after exercise.
\end{abstract}

Keywords: eccentric, concentric and isometric contraction; muscle fatigue and damage; muscle length, muscle force; rate of muscle torque development

\section{INTRODUCTION}

$\mathrm{T}$ The well documented symptoms of exerciseinduced muscle damage (EIMD) include prolonged impairment of muscle function as measured in voluntary and electrically-induced contractions (Warren et al., 1999; Byrne et al., 2004; Skurvydas et al., 2006). In addition, there is strong evidence for low frequency fatigue (LFF) (Skurvydas et al., 2006), protein leakage from injured muscle fibres, acute inflammation reaction and delayed-onset muscle soreness, stiffness and swelling (Chapman et al., 2008; Skurvydas et al., 2008). It is generally agreed that there are two prominent signs of damage in the muscle immediately after it has been subjected to a series of eccentric contractions. These are the presence of disrupted force-bearing structures and damage to 
excitation-contraction coupling system (Warren et al., 1999; Proske, Morgan, 2001).

It has been established that muscle damaging exercise decreases muscle isometric, concentric and eccentric contraction force (Warren et al., 1999; Michaut et al., 2003; Byrne et al., 2004; Skurvydas et al., 2006; Hubal et al., 2008), rightward shift in the optimum joint angle for voluntary isometric (Proske, Morgan, 2001; Philipou et al., 2004; McHugh, Tetro, 2003; Chen et al., 2007) as well concentric strength (Yeung S. S., Yeung E. W., 2008), impairment in voluntary activation more at shorter muscle length (Prasartwuth et al., 2006). The following issues, however, have not been cleared up, yet, namely: 1) what are length-dependent changes in quadriceps muscle torque during isometric as well as in concentric contraction, 2) are there differences between changes in maximal voluntary isometric contraction torque (MVC) and rate of torque development (RTD), what is the relationship between the changes in different muscle mechanical characteristics after muscle damaging eccentric exercise? The primary aim of the present study was to clarify these issues.

\section{RESEARCH METHODS}

Subjects. Healthy untrained men (mean \pm SD: age $=24.8 \pm 3.7$ years, body weight $=78.24 .7 \mathrm{~kg}$, height $=179.9 \pm 3.6 \mathrm{~cm}, \mathrm{n}=10$ ) took part in this study. The untrained subjects were physically active but did not take part in any formal physical exercise or sport program. They had not been involved in any specific fitness training programs during recent years. Each subject read and signed written informed consent form consistent with the principles outlined in the Declaration of Helsinki. The Ethics Committee of Kaunas University of Medicine approved this study.

Muscle damaging eccentric exercise (EE). The subjects performed EE: 10 series of 12 eccentric repetitions with maximal intensity at the angle velocity of $160 \mathrm{deg} / \mathrm{s}$ (the range of knee angle was from 150 to $70 \mathrm{deg}$; full knee extension - $180 \mathrm{deg}$ ). Time period between series was $1 \mathrm{~min}$. Subjects were asked to perform every repetition with maximal effort. The first and the last repetitions in each series were omitted from analysis. The average peak eccentric torque (ET) in a each series was used to calculate the fatigue index (FI) as follows: $\mathrm{FI}=(1 \mathrm{st}$ series ET -10 th series ET $) / 1$ st series ET $\times 100 \%$.
Isometric torque. The isometric torque of knee extensor muscles was measured using an isokinetic dynamometer (System 3; Biodex Medical Systems, Shiley, New York). The sensitivity of the Biodex System 3 in torque measurements is $\pm 1.36 \mathrm{~N} \cdot \mathrm{m}$. The subjects sat upright in the dynamometer chair with the knee joint positioned at 130 and 90 degrees angle. The subjects were ask to perform maximal voluntary contraction force (MVC) as fast as possible at the knee angles of 90 and 130 degrees, for long (LL) and short (SL) muscle length, respectively. The subjects were asked to develop MVC and hold it about $4-5 \mathrm{~s}$. MVC was tested three times in both angles. In all cases muscle torque registrations at different angles were taken randomly. The rest interval between MVC measurements was $1 \mathrm{~min}$. Fatigue index (FI) in percent was calculated according to the formula: (Torque value before EE - Value after EE) / Value before EE/100 per cent. The peak rate of torque development (RTD) was calculated. RTD was defined as the maximal slope of the force time curve (Dforce / Dtime).

Isokinetic torque (IT) measurement. The subjects were asked to perform three continuous repetitions of knee extension with maximal intensity at angle velocity $30 \mathrm{deg} / \mathrm{s}$. The angle range was from 70 to $150 \mathrm{deg}$ (full knee extension - $180 \mathrm{deg}$ ). The knee flexion was not required to perform (knee was set passively at start position). Isokinetic torque (IT) (average of three repetitions) at different angles, i. e. at 80, 90, 100, 110, 120 and 130 degrees was measured. Besides, the optimal degree which gave optimal isokinetic torque (ITopt) was established.

Electromyography. This study used a portable Biometric Datalog system for the transportability to the older adult participants who resided in an independent senior-living community setting. Four channels were used: one for the ground and three for the EMG sensors. The high-pass filter was set at $20 \mathrm{~Hz}$ and the low-pass filter was set at $450 \mathrm{~Hz}$. The EMG data were recorded and stored with the Biometrics Datalog programmable data acquisition unit. This portable unit allowed us to collect sampled digitized data from the reusable EMG sensors. The sampling rate was 1000 samples/s. The SX230 surface EMG sensor is used with DataLOG to collect data of muscle electrical activity. Bipolar surface electrodes (diameter $10 \mathrm{~mm}$, center to center distance $20 \mathrm{~mm}$ ) were placed over the vastus medialis, vastus lateralis and rectus femoris of the 
right leg. The longitudinal axes of the electrodes were in line with the presumed direction of the underlying muscle fibers. All electrode positions were carefully determined and marked to ensure identical pre- and post-exercise recording sites. EMG electrodes were directly connected to custom built differential pre-amplifiers (gain 1000, input impedance of $10 \mathrm{M} \Omega$, common mode rejection $96 \mathrm{~dB}$ at $60 \mathrm{~Hz}$ ) and taped to the skin. Input noise level was less than $5 \mu \mathrm{V}$. Root mean square (rms) EMG amplitudes were determined for the distinct time intervals $0-100 \mathrm{~ms}$ during explosive contraction as well as during maximal voluntary contraction at 2-3 s.

Rectal and muscle temperatures measurement. Rectal $\left(\mathrm{T}_{\mathrm{re}}\right)$ and muscle temperatures $\left(\mathrm{T}_{\mathrm{mu}}\right)$ in 6 subjects were measured before and after EE. $\mathrm{T}_{\mathrm{re}}$ was measured with a thermocouple (Rectal Probe, Ellab, Hvidovre, Denmark) inserted to a depth of $12 \mathrm{~cm}$ past the anal sphincter. The intramuscular temperature was measured with a needle microprobe (MKA, Ellab, Hvidovre, Denmark) inserted into $3-\mathrm{cm}$ depth under the skin covering $\mathrm{m}$. vastus lateralis of the left leg.

Plasma creatine kinase (CK) activity. Approximately $5 \mathrm{ml}$ of blood was drawn from vena cubiti media of the arm at each measurement time point (before exercise as well as $48 \mathrm{~h}$ after exercise). Plasma samples were pipetted into microcentrifuge tubes and stored in a $-20^{\circ} \mathrm{C}$ freezer until analysis. Plasma CK (IU/L) activity was determined by using automatic biochemical analyzer "Monarch" (Instrumentation Laboratory SpA, USA-Italy).

Muscle soreness. Muscle soreness was reported subjectively using a visual analogue scale of 0 to 10 , where 0 represented "no pain" and 10 represented "intolerably intense pain". These muscle soreness evaluation methods have also been used in our previous research (Skurvydas, et al. 2006, 2008). The participants were required to indicate the severity of soreness in their quadriceps in response to muscle compression, as well as when standing up and walking at the start of each daily session.

Experimental protocol. Three-five days before the experiment thesubjects were introduced to different tasks of voluntary performance. After measuring CK in the blood, $\mathrm{T}_{\mathrm{re}}$ and $\mathrm{T}_{\mathrm{mu}}$ the subject was seated in the experimental chair and after 5 min, MVC was tested. About 3 min later three IT at $30 \mathrm{deg} / \mathrm{s}$ were performed. About $3 \mathrm{~min}$ later the EE was undertaken. Two min after EE registering of the same contractile properties was started (they were registered 2-10 min). Besides, at $24 \mathrm{~h}$ and 48 $\mathrm{h}$ after EE muscle soreness as well as CK activity at $48 \mathrm{~h}$ after EE was determined.

Data and statistical analysis. Descriptive data are presented as means \pm SD. Significant effects were found, post hoc testing was performed applying paired t-tests with a Bonferroni correction for multiple comparisons. The level of significance was set at 0.05 . In order to evaluate the relationship between changes in different indicators of voluntary induced muscle performance after EE Pearson's correlation coefficient was established. Based on alpha level of 0.01 , sample size $(n=11)$ standard deviations and average level before and after eccentric exercise statistical power was calculated for all mechanical indicators. Statistical power in all cases was more than 80 per cent.

\section{RESEARCH RESULTS}

Eccentric torque during exercise. The eccentric torque $(\mathrm{ET})$ decreased by $27.9 \pm 9.9 \%(\mathrm{p}<0.001)$ at the end of exercise (Figure 1). The $\mathrm{T}_{\mathrm{re}}$ increased from $37.1 \pm 0.3^{\circ} \mathrm{C}$ degrees to $38.2 \pm 0.2^{\circ} \mathrm{C}$ degrees $(\mathrm{p}<0.01), \mathrm{T}_{\mathrm{mu}}$ from $36.9 \pm 0.4^{\circ} \mathrm{C}$ degrees to $39.5 \pm$ $0.3^{\circ} \mathrm{C}$ degrees $(\mathrm{p}<0.001)$ after exercise. Within 24 $\mathrm{h}-48 \mathrm{~h}$ after EE the subjects felt an acute muscle pain (5-6 points). The plasma CK activity $48 \mathrm{~h}$ after EE had increased up to $680.4 \pm 594.2 \mathrm{IU} / \mathrm{L}$ ( $p<0.01$, compared to before level, $119.7 \pm 48.7$ $\mathrm{IU} / \mathrm{L})$.

The muscle length and contraction type effect on changes in muscle voluntary performance after EE. MVC was significantly greater at LL compared to SL before exercise $(280.3 \pm 47.5$ $\mathrm{N} \cdot \mathrm{m}$ and $246.4 \pm 33.1 \mathrm{~N} \cdot \mathrm{m}$, respectively), but for relative RTD the reverse was true (Figure 2). However, there was a significant change in absolute values of RTD after EE (before EE: $3695 \pm 803 \mathrm{~N} \cdot \mathrm{m} / \mathrm{s}$ and $2360 \pm 695 \mathrm{~N} \cdot \mathrm{m} / \mathrm{s}$ at SL and LL respectively; after EE: $2574 \pm 843 \mathrm{~N} \cdot \mathrm{m} / \mathrm{s}$ and $1517 \pm 476 \mathrm{~N} \cdot \mathrm{m} / \mathrm{s}$ at SL and LL respectively). Before EE it was only in $v$. lateralis muscle that EMG $(\mathrm{rms})$ was significantly $(\mathrm{p}<0.01)$ greater during $100 \mathrm{~ms}$ at SL compared to LL, i. e. $0.26 \pm$ $0.13 \mathrm{mV}$ and $0.15 \pm 0.06 \mathrm{mV}$ respectively. There was a significant difference between EMG (rms) in MVC at LL and SL, i. e. in v. lateralis $0.32 \pm$ $0.12 \mathrm{mV}$ and $0.24 \pm 0.1 \mathrm{mV}$ and in $r$. femoris 0.25 $\pm 0.11 \mathrm{mV}$ and $0.17 \pm 0.07 \mathrm{mV}$ respectively. 
Figure 1. The changes in eccentric torque (ET) during 10 series of 12 eccentric contractions at $160 \mathrm{deg} / \mathrm{s}$

Note. $*-p<0.05$, compared to preexercise values.

Figure 2. The rate of torque development (RTD) at knee angle of 130 and 90 degrees before and after exercise

Note. ${ }^{*}-\mathrm{p}<0.05$, compared between 130 and 90 degrees.

Figure 3. The fatigue index (FI) after eccentric exercise (10 series of 12 repetitions)

Note. MVC, RTD, ITopt., ET - maximal voluntary contraction torque, rate of torque development, optimal isokinetic torque and eccentric * $*^{*}<0.05$, compared to pre-exercise values.
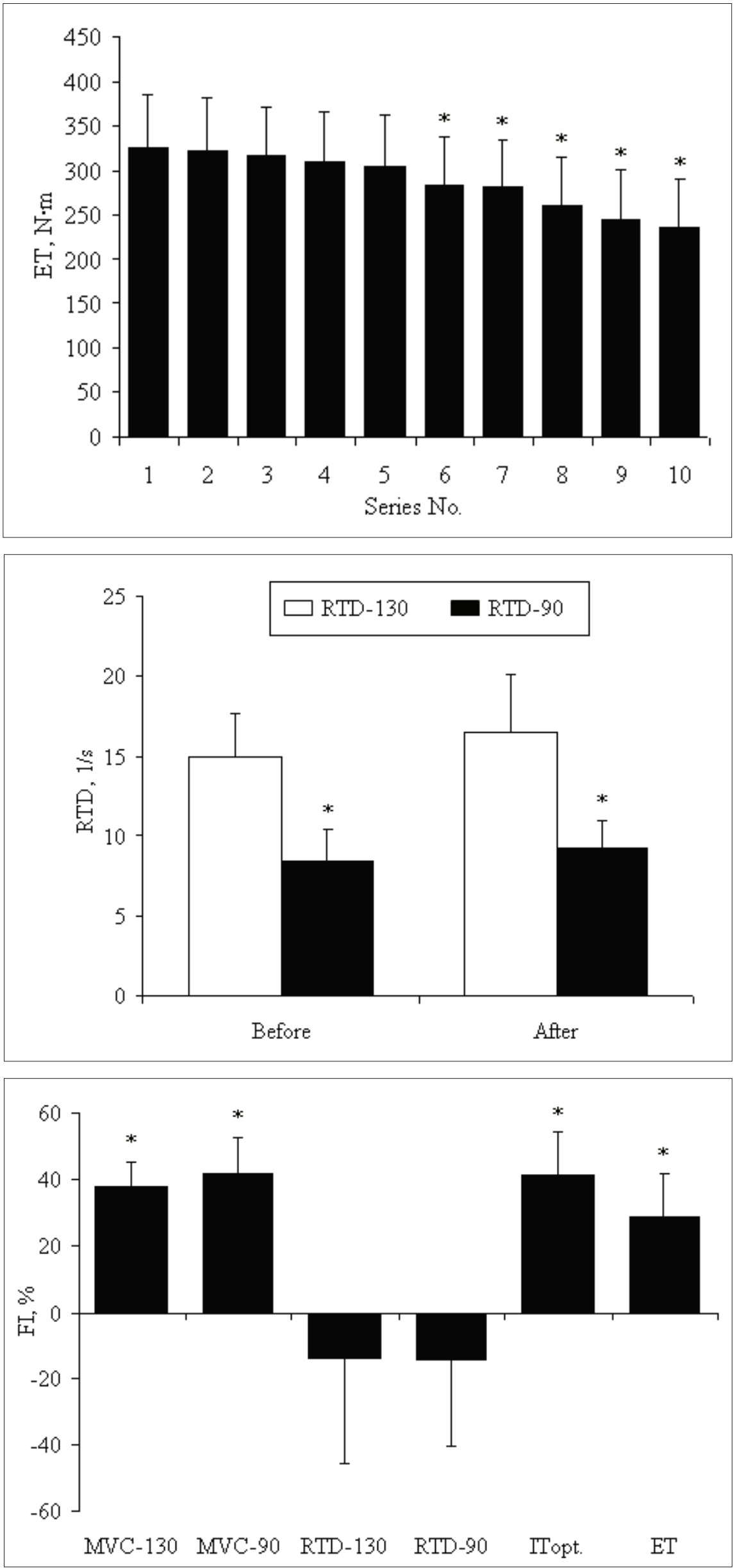


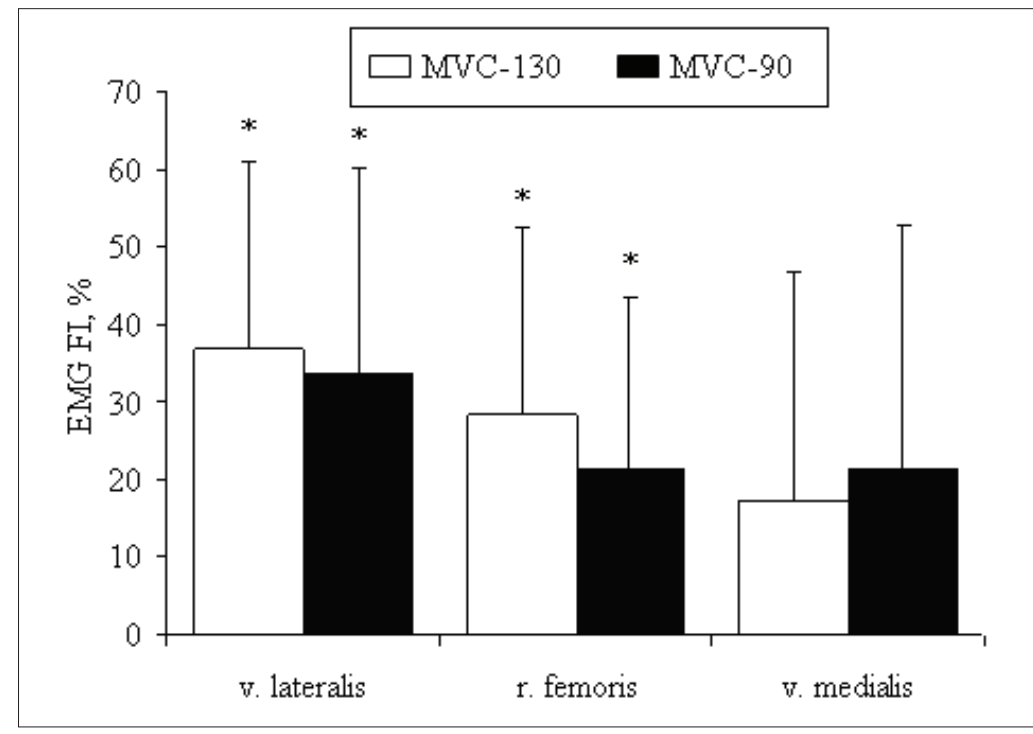

Figure 4. The changes in EMG (rms) during maximal voluntary contraction at 130 and 90 knee angle degrees after eccentric exercise

Note. $*-p<0.05$, compared to pre-exercise values.

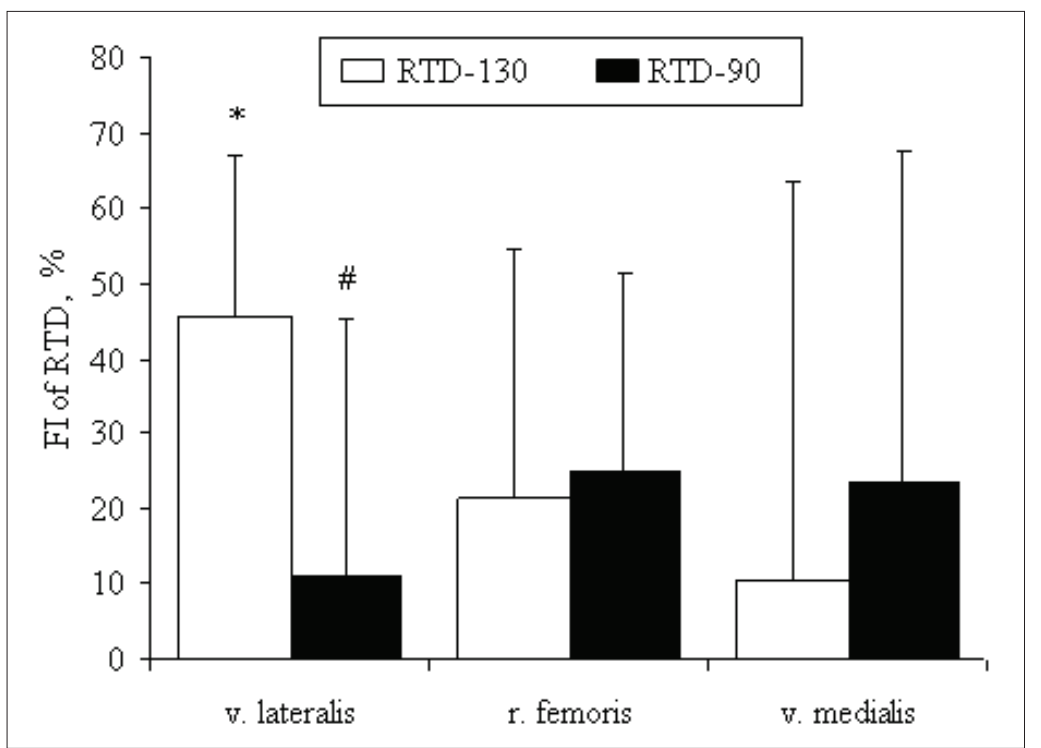

Figure 5. The changes in EMG (rms) during 100 ms after onset of explosive isometric contraction at 130 and 90 knee angle degrees after eccentric exercise

Figures 2 and 3 show that all criteria of voluntary performace changed significantly $(\mathrm{p}<$ 0.001) after EE except for RTD, i. e. increased after EE. The changes in MVC and RTD did not depend on muscle length. However, the FI of MVC as well as ITopt was significantly greater than FI of ET. There was a significant decrease in EMG (rms) of v. lateralis and $r$. femoris after EE during MVC and it did not depend on muscle length (Figure 4). The results showed that EMG (rms) during $100 \mathrm{~ms}$ after onset of explosive isometric contraction decreased significantly after EE only in v. lateralis and only at 130 knee degrees (Figure 5).

\section{DISCUSSION}

The main findings of this study are: 1) lengthdependent changes after eccentric exercise of quadriceps muscle torque are dependent on contraction type: more fatigue at shorter length manifests itself only during concentric isokinetic contraction; 2) RTD does not change after EE.

The main causes of changes in neuromuscular function after eccentric exercise. It has been recently concluded that there is no easy explanation for the strength loss following eccentric contractions since strength loss is a result of complex interaction of various mechanisms (Butterfield, Herzog, 2005; Prasartwuth et al., 2006). However, there is no doubt that in our case the main reasons for the decrease in voluntary induced muscle performance after $\mathrm{EE}$ are related to damage force-bearing structures (Clarkson, Hubal, 2002), excitationcontraction coupling system (Proske, Morgan, 2001; Skurvydas, et al., 2006) as well as changes in voluntary activation of muscle (Prasartwuth et al., 2006). After performing EE indirect symptoms of muscle damage manifested themselves within 24 $\mathrm{h}-48 \mathrm{~h}$ after the load: the rise of muscle soreness, the increased CK activity, the decreased MVC, 
ET and ITopt (Figures 1 and 3), the shift ITopt to longer muscle length. The decreases in EMG (rms) during MVC after EE (Figure 4) shows that central fatigue might occur in our case.

Changes in MVC and RTD. It has been concluded that eccentric exercise-induced torque decrease is not contraction type dependent (Michaut et al., 2002) or ET decreased more than isometric one after ten sets of ten maximal concentric knee extensions (Michaut et al., 2003). V. Linnamo et al. (2000) established that ET decreased more than concentric torque after 100 maximal eccentric actions. In our case, however, ET decreased significantly less than ITopt (Figure 3). J. B. Thorlund et al. (2008) showed that MVC (about 10 per cent) and RTD decreased by $16-20$ per cent following handball match play. However, MVC decreased in our case by about 30-40 percent while relative RTD did not change significantly (Figure 2). While maximum voluntary strength largely depends on the cross sectional area of the muscle, RTD is basically related to the discharge rate of the motor units recruited (Van Cutsem et al., 1998) and to the recruitment characteristics of motor units (Duchateau, Hainaut, 2003), that is it depends on neuromuscular drive of human skeletal muscle (Aagaard et al., 2002). There is no doubt that the efferent neuromuscular drive of human skeletal muscle is decreased after EE. This is in accord with our data that there is a significant change in absolute RTD after EE as well as in EMG (rms) during $100 \mathrm{~ms}$ of RTD at SL (Figure 5). Despite this, the changes in RTD after EE might be diminished by elevated muscle temperature of about $2.6 \mathrm{C}$ degrees. It has been established by A. J. Sargeant (1987) that raising muscle temperature to a similar level increases RTD.

Length-dependent changes in isokinetic torque. To our knowledge it is the first study to have shown that there are length-dependent changes in the voluntary knee extension torque after EE: shorter muscle length, more fatigue index (Figure 6). Thought it is rather difficult to accurately determine the optimal angle due to flat torque at different angles but in our cases there is not any doubt that significantly more changes occur in torque at SL compared to LL (Figure 6). The rightward shift in the muscle length-tension relationship has been attributed to an increased series compliance of the muscle due to disrupted sarcomeres (Proske, Morgan, 2001; Gregory et al., 2007) and this shift has been proposed as a reliable indicator of muscle damage (Proske, Morgan, 2001; Philippou et al., 2004; Chen et al., 2007) as well as muscle fatigue (Butterfield, Herzog, 2006). This is in accord with our data, namely, that shift of optimal angle is significantly related to CK 48 after as well as to changes in ET after EE.

S. S. Yeung and E. W. Yeung (2008) also tested the optimal angle shift during isokinetic contraction (at $60 \mathrm{deg} / \mathrm{s}$ ). They found that after 10-minute stepping eccentric exercise there was a significant shift (about 4 degrees) in the peak torque angle to longer muscle lengths. Similar optimal angle shift (about 4 degrees) in isometric contraction after 30 eccentric actions was found by T. C. Chen et al. (2007). However, in our case the optimal angle shift to longer muscle length was much greater (about 12 degrees). This discrepancy might be explained by the fact that our eccentric exercise was much more intensive and therefore much greater muscle fatigue as well muscle damage was induced. It is rather strange that there are no length dependent changes in isometric MVC after EE, while this is observed during isokinetic contraction. It might be related to the fact that we tested MVC only at two angles, i. e. at 130 and $90 \mathrm{deg}$.

\section{CONCLUSIONS AND PERSPECTIVES}

We observed more changes in isokinetic torque at shorter muscle length after eccentric exercise induced muscle fatigue and damage. The changes in isometric MVC and RTD after eccentric exercise did not depend on the length of the muscle tested. Besides, relative RTD did not change after exercise.

Coaches, trainers and athletes need to be aware of the impact of exercise-induced muscle damage on the changes in length-related isokinetic torque in dynamic movements. The force decrease in any part of the range of motion during the exercises might affect overall performance. This study demonstrates that the effect of severe muscledamaging exercises on isokinetic torque is the greatest at short muscle length, but this is not evident than performing isometric contractions. Therefore, these findings should be considered when applying this type of exercises and evaluating muscle function at a particular point in time. 


\section{REFERENCES}

Aagaard, P., Simonsen, E. B., Andersen, J. L., Magnusson, P., Dyhre-Poulsen, P. (2002). Increased rate of force development and neural drive of human skeletal muscle following resistance training. Journal of Applied Physiology, 93, 1318-1326.

Butterfield, T. A., Herzog, W. (2005). Quantification of muscle fiber strain during in-vivo repetitive stretchshortening cycles. Journal of Applied Physiology, 99, 593-602.

Butterfield, T. A., Herzog, W. (2006). The magnitude of muscle strain does not influence serial sarcomere number adaptations following eccentric exercise. Pflügers Archiv: European Journal of Physiology, 451, 688-700.

Byrne, C., Twist, C., Eston, R. (2004). Neuromsucular function after exercise-induced muscle damage. Theoretical and applied implications. The Journal of Sports Medicine, 1, 49-69.

Chapman, D. W., Newton, M. J., Zainuddin, Z., Sacco, P., Nosaka, K. (2008). Work and peak torque during eccentric exercise do not predict changes in markers of muscle damage. British Journal of Sports Medicine, 42, 585-591.

Chen, T. C., Nosaka, K., Sacco, P. (2007). Intensity of eccentric exercise, shift of optimum angle, and the magnitude of repeated-bout effect. Journal of Applied Physiology, 102, 992-999.

Clarkson, P. M., Hubal, M. J. (2002). Exercise-induced muscle damage in humans. American Journal of Physical Medicine \& Rehabilitation, 81, S 52-69.

Van Cutsem, M., Duchateau, J., Hainaut, K. (1998). Changes in single motor unit behaviour contribute to the increase in contraction speed after dynamic training in humans. Journal of Physiology (London), 513, 295-305.

Duchateau, J., Hainaut, K. (2003). Mechanisms of muscle and motor unit adaptation to explosive power training. In P. V. Komi (Ed.), Strength and Power in Sport. Blackwell, Oxford. P. 315-330.

Gregory, J. E., Morgan, D. L., Allen, T. J., Proske, U. (2007). The shift in muscle's length-tension relation after exercise attributed to increased series compliance. European Journal of Applied Physiology, 99, 431-441.

Hubal, M. J., Rubinstein, S. R., Clarkson, P. M. (2008). Muscle function in men and women during maximal eccentric exercise. Journal of Strength \& Conditioning Research, 22, 1332-1338.

Linnamo, V., Bottas, R., Komi, P. V. (2000). Force and EMG power spectrum during and after eccentric and concentric fatigue. Journal of Electromyography \& Kinesiology, 10, 293-300.
McHugh, M. P., Tetro, D. T. (2003). Changes in relationship between joint angle and torque production associated with repeated bout effect. Journal of Sports Sciences, 21, 927-932.

Michaut, A., Pousson, M., Babault, N., Van Hoecke, J. (2002). Is eccentric exercise-induced torque decrease contraction type dependent? Medicine \& Science in Sports \& Exercise, 34, 1003-1008.

Michaut, A., Pousson, M., Millet, G., Belleville, J., Van Hoecke, J. (2003). Maximal voluntary eccentric, isometric and concentric torque recovery following a concentric isokinetic exercise. International Journal of Sports Medicine, 24, 51-56.

Philippou, A., Bogdanis, G. C., Nevill, A. M., Maridaki, M. (2004). Changes in the angle-force curve of human elbow flexors following eccentric and isometric exercise. European Journal of Applied Physiology, 93, 237-244.

Prasartwuth, O., Allen, T. J., Butler, J. E., Gandevia, S. C. (2006). Length-dependent changes in voluntary activation, maximum voluntary torque and twitch responses after eccentric damage in humans. Journal of Physiology, 15, 243-252.

Proske, U., Morgan, D. L. (2001). Muscle damage from eccentric exercise: mechanism, mechanical signs, adaptation and clinical applications. Journal of Physiology (London), 537, 333-345.

Sargeant, A. J. (1987). Effect of muscle temperature on leg extension force and short-term power output in humans. European Journal of Applied Physiology, 56, 693-698.

Skurvydas, A., Kamandulis, S., Stanislovaitis, A. et al. (2008). Leg immersion in warm water, stretch-shortening exercise, and exercise-induced muscle damage. Journal of Athletic Training, 43, 592-599.

Skurvydas, A., Sipaviciene, S., Krutulyte, G. et al. (2006). Dynamics of indirect symptoms of skeletal muscle damage after stretch-shortening exercise. Journal of Electromyography \& Kinesiology, 16, 629636.

Thorlund, J. B., Michalsik, L. B., Madsen, K., Aagaard, P. (2008). Acute fatigue-induced changes in muscle mechanical properties and neuromuscular activity in elite handball players following a handball match. Scandinavian Journal of Medicine \& Science in Sports, 18, 462-472.

Warren., G. L., Lowe, D. A., Armstrong, R. B. (1999). Measurement tools used in the study of eccentric contraction-induced injury. Sports Medicine, 27, 43-59. Yeung, S. S., Yeung, E. W. (2008) Shift of peak torque angle after eccentric exercise. International Journal of Sports Medicine, 29, 251-256. 


\title{
VALINGŲ EKSCENTRINIŲ PRATIMŲ SUKELTO NUOVARGIO PRIKLAUSOMUMAS NUO RAUMENU ILGIO IR SUSITRAUKIMO TIPO
}

\author{
Albertas Skurvydas, Marius Brazaitis, Sigitas Kamandulis, \\ Dalia Mickevičienė, Diana Karanauskienė \\ Lietuvos kūno kultūros akademija, Kaunas, Lietuva
}

\section{SANTRAUKA}

Tyrimo pagrindimas ir hipotezė. Iškèlème hipotezę, kad ekscentrinis krūvis (EK) sukels raumenų nuovargi ir pažeidą, kuri priklausys ne tik nuo testuojamo raumens ilgio, bet ir nuo susitraukimo tipo (ekscentrinis vs. koncentrinis vs. izometrinis).

Tikslas: patikrinti tyrimo hipotezę.

Metodai. Sveiki netreniruoti vyrai (vidurkis \pm standartinis nuokrypis: amžius $-24,8 \pm 3,7 \mathrm{~m} ., \mathrm{n}=10$ ) atliko 10 serijų po 12 kartojimų ekscentrinių keturgalvio šlaunies raumens susitraukimų esant fiksuotam 160\% kampiniam greičiui. Prieš ir po EK matavome maksimaliają valingą keturgalvio raumens izometrinio susitraukimo jègą (MVJ), maksimalu jègos didèjimo laipsni (JDL) ir izokinetinę jëgą esant fiksuotam $30 \% \mathrm{~s} \mathrm{kampiniam} \mathrm{greičiui.} \mathrm{Visi} \mathrm{matavimai}$ atlikti sulenkus kelio sąnari skirtingu kampu. Be to, buvo matuojamas keturgalvio raumens elektrinis aktyvumas (EMG).

Rezultatai. Nustatytas reikšmingas JDL absoliučių reikšmių pokytis po EK (prieš EK: $3695 \pm 803 \mathrm{~N} \cdot \mathrm{m} / \mathrm{s}$ ir $2360 \pm 695 \mathrm{~N} \cdot \mathrm{m} / \mathrm{s}$ esant mažam ir dideliam raumens ištempimo ilgiui atitinkamai; po EK: $2574 \pm 843 \mathrm{~N} \cdot \mathrm{m} / \mathrm{s}$ ir $1517 \pm 476 \mathrm{~N} \cdot \mathrm{m} / \mathrm{s}$ esant mažam ir dideliam raumens ištempimo ilgiui atitinkamai). Aptiktas reikšmingas skirtumas tarp EMG reikšmiu atliekant MVJ po EK, kai raumens ištempimo ilgis didelis ir mažas atitinkamai: šlaunies šoninio plačiojo (v. lateralis) raumens $0,32 \pm 0,12 \mathrm{mV}$ ir $0,24 \pm 0,10 \mathrm{mV}$; tiesiojo šlaunies (r. femoris) raumens $0,25 \pm$ $0,11 \mathrm{mV}$ ir $0,17 \pm 0,07 \mathrm{mV}$. Visi valingomis pastangomis paveikti rodikliai sumažejo reikšmingai, išskyrus JDL (t. y. pastarasis padidèjo po EK).

Aptarimas ir išvados. Didesni izokinetinès jègos pokyčiai po EK sukelto raumens nuovargio ir pažeidos buvo nustatyti esant mažesniam raumens ištempimo ilgiui. Nustatyti MVJ ir JDL pokyčiai po EK nepriklauso nuo testuoto raumens ištempimo ilgio. Be to, santykinis JDL po EK reikšmingai nepakito.

Raktažodžiai: ekscentriniai, koncentriniai ir izometriniai susitraukimai, raumens nuovargis ir pažeida, raumens ilgis, raumens jèga, jègos momento išugdymo greitis. 